\title{
Gastric Helicobacter pylori infection associates with an increased risk of colorectal polyps in African Americans
}

\author{
Hassan Brim ${ }^{1 \dagger}$, Marwah Zahaf ${ }^{2 \dagger}$, Adeyinka O Laiyemo ${ }^{2}$, Mehdi Nouraie ${ }^{3}$, Guillermo I Pérez-Pérez ${ }^{4}$, Duane T Smoot ${ }^{2}$, \\ Edward Lee ${ }^{1}$, Hadie Razjouyan ${ }^{6}$ and Hassan Ashktorab ${ }^{2,5^{*}}$
}

\begin{abstract}
Background: Gastric Helicobacter pylori (H. pylori) infection and colorectal polyps are more prevalent in African Americans than in the general population. We aimed to investigate whether gastric $\mathrm{H}$. pylori infection is associated with colorectal polyps in African Americans.

Methods: Medical records of African Americans, 40 years and older $(n=1256)$ who underwent bidirectional gastrointestinal endoscopy on the same day were reviewed. H. pylori status was assessed by immunohistochemistry on gastric specimens. Colorectal polyps were confirmed by histological examination of colorectal biopsies. A subset of serum samples from healthy and polyp-bearing patients $(n=163)$ were analyzed by ELISA for anti-H. pylori and anti-CagA antibodies. The crude and adjusted effect of $\mathrm{H}$. pylori on the risk of colorectal adenoma and polyp were computed by logistic regression models.

Results: The prevalence of colorectal polyps and adenomas were 456 (36\%) and 300 (24\%) respectively. Colorectal polyps were more prevalent in gastric H. pylori infected than non-infected subjects [43\% vs. 34\%; Odds Ratio (OR) (95\% Cl): 1.5 (1.2-1.9), $P=0.001]$. Patients with $H$. pylori-associated chronic active gastritis were at high risk to have adenomas [Unadjusted OR (95\% Cl): $1.3(1.0-1.8) ; P=0.04]$. There was no difference in histopathology, size, or location of polyps with respect to $H$. pylori status. Gastric H. pylori infection, age, male gender and high risk clinical presentations were independent risk factors for colorectal polyps. Serological testing also revealed a higher prevalence of $H$. pylori and its toxin Cag-A in polyp patients vs. non polyp patients' sera, although in a non-statistically significant manner.

Conclusions: This study showed that current gastric H. pylori infection is associated with an increased risk of colorectal polyps in African Americans. Patients with H. pylori induced gastritis may benefit from early screening colonoscopy as a preventative measure for colorectal cancer.
\end{abstract}

Keywords: African Americans, H. pylori infection, Colorectal neoplasm, Gastric lesion, Risk factors, Forty year and older

\section{Background}

Colorectal cancer (CRC) is the third most common cancer and the third most common cause of cancer deaths in both men and women in US [1]. In its sporadic form, CRC mostly arises from adenomatous polyps (adenomas). CRC can also arise from hyperplastic polyps [2,3]. Early

\footnotetext{
*Correspondence: hashktorab@howard.edu

${ }^{\dagger}$ Equal contributors

${ }^{2}$ Department of Medicine and Cancer Center, Howard University, Washington, DC, USA

${ }^{5}$ Cancer Center and Department of Medicine, Howard University College of Medicine, 2041 Georgia Avenue, NW, Washington, DC 20060, USA

Full list of author information is available at the end of the article
}

detection and removal of colorectal polyps have led to a decrease in the incidence and mortality from CRC [4-6]. Recent interest have been directed toward CRC prevention and the possible role of infectious agents in the polyp to cancer sequence [7-10]. For instance, many epidemiological studies have linked $H$. pylori's infection to colorectal neoplasm either through high prevalence of $H$. pylori seropositivity among CRC or colorectal polyp patients [11-14], or through the presence of bacterial byproducts and their trophic effects on colon mucosa [15-18], while

\section{Biomed Central}

(c) 2014 Brim et al.; licensee BioMed Central Ltd. This is an Open Access article distributed under the terms of the Creative Commons Attribution License (http://creativecommons.org/licenses/by/2.0), which permits unrestricted use, distribution, and reproduction in any medium, provided the original work is properly credited. 
others disagree [19-22]. Moreover, few studies have linked current $H$. pylori in the stomach [23] or colon [24-29] with colon cancer and/or polyps.

It is well known that $H$. pylori predisposes to the development of gastric cancer precursor lesions, thus it has been classified as class 1 carcinogen [30]. A recent publication by Sonneberg et al. revealed a wide range of effects of gastric $H$. pylori on the gastrointestinal tract with diseases that are inversely associated with $H$. pylori, such as reflux disease, erosive oesophagitis, Barrett's oesophagus, and oesophageal adenocarcinoma, showing a striking rise during the recent decline of $H$. pylori infection in the general population [31]. Whether $H$. pylori's effect on gastric mucosa predicts its effect on colon mucosa is still controversial. Indeed, a recent meta-analysis of the correlation between $H$. pylori and extra-gastric malignancies revealed a modest statistically significant relationship of $H$. pylori infection with both colon cancer and polyps [32]. H. pylori's infection and colorectal lesions appear to be more common in African Americans compared to the Caucasian population in the US $[1,33]$. We sought to determine whether current gastric $H$. pylori infection was associated with the presence of colorectal polyps in a population at high risk for colorectal lesions.

\section{Methods}

\section{Patients' selection}

We retrospectively reviewed the medical records of 1920 patients of which 1256 were included in the present study. The 1256 retained records correspond to African American patients, 40 years and older who underwent bidirectional endoscopy (complete colonoscopy and gastroscopy) at the same day from January 2005 to August 2009. The study was conducted at Howard University Hospital, a tertiary hospital serving predominantly African Americans in the District of Columbia, USA. The study was approved by the Howard University Hospital Institutional Review Board and we obtained consent from patients who provided blood samples for the serological analysis. Demographic variables included gender, race and age. Clinical and pathological data were collected with respect to reasons for undergoing bidirectional endoscopies, H. pylori immunohistochemistry (IHC) status of gastric biopsies, histo-pathological diagnosis of gastric specimens, and colorectal polyps' type, size, grade of dysplasia and location. We divided our patients into high and average risk for colorectal polyps based on their presentations [34,35]. High risk patients were those with lower gastrointestinal (GI) blood loss, abdominal mass [34,35], and/or family/ personal history of colorectal polyps or cancer [36]. Average risk patients were either asymptomatic and undergoing screening colonoscopy or suffered abdominal pain, epigastric pain unresponsive to treatment, acid peptic symptoms, change in bowel habits, weight loss or anemia. Patients were excluded if they had inflammatory bowel disease, malignancies including colorectal cancer, suboptimal bowel preparations, incomplete colonoscopies, and lack of data regarding $H$. pylori immunohistochemistry examination of gastric biopsies.

\section{Specimens}

Gastric biopsies were taken during gastroscopy and were labeled as antrum, body, and fundus. Both gastric biopsies and colorectal polyps (when encountered) were harvested by biopsy, snare, piecemeal excision, or saline assisted endoscopic mucosal resection. Colorectal polyps were divided by location. Polyps located in cecum, ascending, and transverse colon were classified as "right sided". Those located in descending colon, sigmoid, and rectum were classified as "left sided". Patients with multiple polyps all over the colon were classified as having "both" right and left colon polyps. All specimens were sent to the pathology department after immersion in formalin. The colorectal polyps size was measured after tissue fixation. H. pylori status was identified using immunohistochemistry staining on gastric biopsies. A Novocastra Liquid mouse monoclonal Anti-H. pylori antibody was used (NCL-L-H. pylori, Clone\#ULC3R, Leica Biosystems). An experienced gastrointestinal pathologist examined the specimens and made the histo-pathological classification of gastric biopsies and colorectal polyps. We classified $H$. pylori associated gastric lesions (independently of their distribution or severity) into chronic active (non-atrophic) gastritis, chronic atrophic gastritis with intestinal metaplasia, reactive gastropathy with foveolar hyperplasia, hyperplastic gastropathy and normal gastric mucosa [37]. We excluded gastric dysplasia and gastric cancers from our study. Colorectal polyps included hyperplastic (non-neoplastic) polyps and adenomatous (neoplastic) polyps. Adenomatous polyps were divided into advanced adenomas (tubular adenoma $\geq 1 \mathrm{~cm}$, adenoma with $>25 \%$ villous component, and/or high grade dysplasia), and non-advanced adenoma (tubular adenoma $<1 \mathrm{~cm}$ ) [6].

\section{Serological tests for the detection of anti-H. pylori and anti-Cag-A in patients' sera}

We determined the presence of anti- $H$. pylori antibodies in serum using 96-well plates coated with $H$. pylori whole cell antigens, according to previously described methods $[38,39]$. All samples, standards and controls were run in duplicate. Serum samples $(n=163)$ were diluted 1:800 and incubated in the 96-well plate for $1 \mathrm{hr}$ at $37^{\circ} \mathrm{C}$. After washing the plates twice using EL $\times 50$ Automated strip washer (Bio-Tek Instruments, Winooski VT), bound antibodies were detected by anti-human IgG linked to horseradish peroxidase (Biosource International, Camarillo, CA) diluted 
1:4000 and incubated for $1 \mathrm{hr}$ at $37^{\circ} \mathrm{C}$. After washing, color development is produced by 2,2'-Azino-bis(3Ethylbenzthiazoline-6-sulfonic acid) (Sigma Chemical Co. St Louis MO). Color in wells was analyzed in a MRX Revelation microplate reader (Dynex technologies INC, Chantilly, VA) at $450 \mathrm{~nm}$ within $30 \mathrm{~min}$. All assays were performed with 4 positive and 2 negative controls. A positive result is one with an OD (optical density) ratio greater than one, as previously reported $[40,41]$. The specificity of this assay is $93.5 \%$ and its sensitivity is $99.4 \%[40,42]$.

For the detection of antibodies against CagA, 96-well plates coated with recombinant CagA protein prepared according to specifications previously reported $[43,44]$. All samples, were run in duplicate. Serum samples were diluted 1:100 and applied to wells and incubated for $1 \mathrm{hr}$ at $37^{\circ} \mathrm{C}$. Plates were washed twice and bound antibodies were detected by anti-human IgG linked to horseradish peroxidase (Biosource). The reporter for bound enzyme is horseradish peroxidase that was detected as mentioned above. Color is read in a microplate reader (Dynex) at $450 \mathrm{~nm}$. Samples with OD ratio values greater than a preestablished cut-off (OD ratio $450=0.350$ ) are considered positive as previously reported [44]. This assay has a specificity of $97 \%$ and a sensitivity of $96 \%$ [43]. Positive and negative controls were sera from biopsy- and culturevalidated individuals obtained locally, in addition to positive and negative controls obtained from previous studies [38].

\section{Statistical analysis}

We used Student's $t$-test to compare the distribution of continuous variables between $H$. pylori positive and negative subjects. For categorical variables, we used Chi-square test. Then we computed unadjusted Odds Ratio (OR) (95\% Confidence Interval [CI]) for potential predictors of colorectal polyps and adenomas. Multivariate logistic regression analysis was applied to compute the adjusted OR (95\% CI) for predictors of colorectal polyps and adenomas. All variables with $\mathrm{P}<0.2$ from bivariate analysis were selected for multivariate logistic regression. The final model was developed with a stepwise backward approach. All variables with $\mathrm{P}$ value $<0.05$ were considered statistically significant and remained in final model. All analyses were done using SPSS 17.0 (SPSS Inc., IL).

\section{Results}

\section{Population and clinicopathological characteristics}

Among 1920 potential participants, 1256 African Americans, aged forty or above, were eligible for this study. NonAfrican American patients $(\mathrm{n}=100)$, as well as patients without bidirectional endoscopy $(n=385)$, patients with inflammatory bowel disease $(\mathrm{n}=146)$ or lacking the $H$. pylori IHC stain $(\mathrm{n}=33)$ were excluded. The prevalence of $H$. pylori infection was $366 / 1256$ (29.1\%) while the prevalence of colorectal polyps and adenomas were 456 (36\%) and 300 (24\%) respectively. The frequency of males was 433 (34\%). The frequency of colorectal adenomas increased with age (from 15\% in patients younger than 50 to $33 \%$ in those 70 years and older, $\mathrm{p}<0.001)$. The same trend was observed for polyps (from 30\% in patients younger than 50 to $39 \%$ in those 70 years and older, $\mathrm{P}=0.033$ ). The mean age (SD) 57 years (9.6) was the same for $H$. pylori infected and non-infected subjects $(\mathrm{p}=0.9)$. The frequency of male gender in $H$. pylori negative and positive patients were $32 \%$ and $41 \%$, respectively $(p=0.004)$. The frequency of chronic active gastritis $(\mathrm{p}<0.001)$ and colon polyps $(\mathrm{p}=0.001)$ were higher in $H$. pylori positive patients. Polyp histology, size and location were not correlated to $H$. pylori status (Table 1 ). Colorectal polyps were located mainly in the left colon (54\%). The same distribution was observed for adenomatous and hyperplastic polyps. Out of 1256 patients, 158 (13\%) had personal or family history of colorectal polyps or cancer. Of these 158 subjects, 63 (40\%) were males, 32 (20\%) were $H$. pylori positive, and 77 (49\%) had colorectal polyps.

By univariate analysis, older age $(\mathrm{p}<0.001)$, male gender $(\mathrm{p}<0.001), H$. pylori positivity $(\mathrm{p}=0.003)$ and chronic active gastritis $(\mathrm{p}=0.04)$ were significantly associated with higher frequency of adenoma (Table 2.a). In a separate analysis, male gender and $H$. pylori were associated with higher frequency of polyps (Table 2.b).

Table 1 Distribution of clinical variables by $H$. pylori status

\begin{tabular}{llll}
\hline & $\begin{array}{l}\text { H. pylori } \\
\text { positive } \\
\mathbf{N}=\mathbf{3 6 6}\end{array}$ & $\begin{array}{l}\text { H. pylori } \\
\text { negative } \\
\mathbf{N}=\mathbf{8 9 0}\end{array}$ & P value \\
\hline Gastric lesions & & & \\
- No gastric lesion, n (\%) & $8(2)$ & $691(78)$ & $<0.001$ \\
- Chronic Active Gastritis, n (\%) & $305(83)$ & $62(7)$ & \\
- Intestinal metaplasia, n (\%) & $46(13)$ & $98(11)$ & \\
- Other lesions, n (\%) & $7(2)$ & $35(4)$ & \\
Polyp, no (\%) & & & \\
Polyp size in cm, mean (SD) ${ }^{1 *}$ & $0.2(0.15)$ & $0.2(0.15)$ & 0.2 \\
Polyp Histology* & & & \\
- Advanced Adenoma, n (\%) & $21(13)$ & $32(11)$ & 0.6 \\
- Non-advanced adenoma, n (\%) & $87(55)$ & $160(54)$ & \\
- Hyperplastic polyp, n (\%) & $50(32)$ & $106(36)$ & \\
Polyp Location ${ }^{1 *}$ & & & \\
- Right side, n (\%) & & & \\
- Left side, n (\%) & $51(32)$ & $95(32)$ & 0.9 \\
\hline
\end{tabular}

"Polyp" label in this table includes adenoma and hyperplastic polyp. *Among subjects with polyps. 
Table 2 Univariate analysis of demographic and clinical variables by adenoma or polyp diagnosis

\begin{tabular}{|c|c|c|c|c|}
\hline 2.a: Adenoma & Adenoma positive $\mathrm{N}=300$ & Adenoma negative $\mathrm{N}=956$ & OR $(95 \% \mathrm{Cl})^{*}$ & $P$ value* \\
\hline Age $\geq 60$ years, $n(\%)$ & $129(43)$ & $295(31)$ & $1.7(1.3-2.2)$ & $<0.001$ \\
\hline Male gender, n (\%) & $132(44)$ & $301(32)$ & $1.7(1.3-2.2)$ & $<0.001$ \\
\hline H. pylori positivity, n (\%) & $108(36)$ & $258(27)$ & $1.5(1.2-2.2)$ & 0.003 \\
\hline Chronic active gastritis, n (\%) & $102(34)$ & $265(28)$ & $1.3(1.0-1.8)$ & 0.04 \\
\hline Baseline high risk, n (\%) & $8(3)$ & $13(1)$ & $2.0(0.7-5.2)$ & 0.1 \\
\hline 2.b: Polyp & Polyp positive $N=456$ & Polyp negative $\mathrm{N}=800$ & OR $(95 \% \mathrm{Cl})^{*}$ & $P$ value* \\
\hline Age $\geq 60$ years, $n$ (\%) & $169(37)$ & $255(32)$ & $1.3(1.0-1.6)$ & 0.06 \\
\hline Male gender, n (\%) & 177 (39) & $256(32)$ & $1.3(1.1-1.7)$ & 0.015 \\
\hline H. pylori positivity, n (\%) & $158(35)$ & $208(26)$ & $1.5(1.2-1.9)$ & 0.001 \\
\hline Chronic active gastritis, n (\%) & $146(32)$ & $221(28)$ & $1.2(1.0-1.6)$ & 0.1 \\
\hline Baseline high risk, n (\%) & $13(3)$ & $8(1)$ & $2.9(1.2-7.1)$ & 0.014 \\
\hline
\end{tabular}

*Unadjusted values.

In multivariate logistic regression, age (adjusted $\mathrm{OR}=1.4$ for each 10 years), male gender (adjusted $\mathrm{OR}=1.7$ ), and $H$. pylori positivity (adjusted OR $=1.5$ ) were independent risk factors for colorectal adenoma (Table 3.a), with similar findings for colorectal polyps (Table 3.b).

\section{Pre-procedure's indications as risk predictors for colorectal polyps}

Using combination criteria of baseline high risk clinical presentations- such as lower GI blood loss, abdominal mass and/or family/personal history of colorectal polyps or cancer, was more sensitive and specific than using each presentation alone in the prediction of colorectal polyps, but not adenoma (Table 2). In multivariate logistic regression, baseline risk features were statistically significant predictors of colorectal polyps (adjusted OR [95\% CI]: 2.9 [1.2-7.1]; $\mathrm{p}=0.021$.

Table 3 Multivariate logistic regression for predictors of colorectal adenoma or polyp

\begin{tabular}{|c|c|c|}
\hline 3.a: Adenoma & Adjusted OR $(95 \% \mathrm{Cl})^{*}$ & $P$ value \\
\hline Age (10 years) & $1.4(1.2-1.6)$ & $<0.001$ \\
\hline Male gender & $1.7(1.3-2.0)$ & $<0.001$ \\
\hline H. pylori positivity & $1.5(1.1-2.0)$ & 0.003 \\
\hline 3.b: Polyp & Adjusted OR $(95 \% \mathrm{CI})^{*}$ & $P$ value \\
\hline Age (10 years) & $1.2(1.1-1.3)$ & 0.005 \\
\hline Male gender & $1.3(1.0-1.7)$ & 0.026 \\
\hline H. pylori positivity & $1.5(1.2-1.9)$ & 0.002 \\
\hline Baseline high risk & $2.9(1.2-7.1)$ & 0.021 \\
\hline
\end{tabular}

\section{Serological assays for the detection of anti-H. pylori and} anti-Cag-A

One hundred sixty three serum samples (including 81 polyp and 82 without polyps gender and age matched subjects) were analyzed for anti- $H$. pylori and anti-CagA antibodies. In these two groups, 85 subjects (45\%) were positive for anti- $H$. pylori. Of these 85 sera, 60 (71\%) were anti-Cag-A positive. The anti-H. pylori positive number in non polyp patients were 40 (49\%) while they were $45(56 \%)$ in the polyp patients' sera $(p=0.3)$ while anti-Cag-A positivity was $73 \%$ in polyp patients vs. $68 \%$ in non polyp controls $(\mathrm{p}=0.5)$. Thirty three $(55 \%)$ patients who were positive for both $H$. pylori and Cag-A had polyps while 33 (47\%) patients of those negative for both $H$. pylori and Cag-A had polyps $(\mathrm{p}=0.3$; Table 4$)$. The corresponding figure for those positive for $H$. pylori and negative for Cag-A was 12 (48\%). While the $\mathrm{p}$ values were not statistically significant, the observed pattern of higher polyp prevalence in $H$. pylori/Cag-A patients is consistent with the overall epidemiological results.

\section{Discussion}

Our study indicates that gastric $H$. pylori infection, confirmed by immunohistochemistry staining of gastric

Table 4 Serological testing for anti-H. pylori (HP) and anti-Cag-A in patients with polyps

\begin{tabular}{llll}
\hline H. pylori status & $\begin{array}{l}\text { Number of } \\
\text { patients }\end{array}$ & Polyps & OR (95\% Cl)* \\
\hline HP Negative & 70 & $33(47 \%)$ & 1 \\
HP Positive & & & \\
HP Ab + \& Cag Ab + & 60 & $33(55 \%)$ & $1.37(0.65-2.90)$ \\
HP Ab + \& Cag Ab - & 25 & $12(48 \%)$ & $1.03(0.37-2.85)$ \\
HP Ab - \& Cag Ab + & 8 & $3(38 \%)$ & $0.67(0.10-3.79)$ \\
Total & 163 & $81(50 \%)$ & \\
\hline
\end{tabular}

*Unadjusted. 
biopsies, associates with an increased risk of colorectal lesions in African Americans. The same association was true in 3 meta-analyses which included studies from different ethnic groups. In particular, Zumkeller et al. [45] included 11 studies regardless of the diagnostic tests used for $H$. pylori, and Zhao et al. [13] included 10 out of 13 case-control studies that used only IgG antibody for $H$. pylori to demonstrate previous $H$. pylori infection in patients with colonic lesions. Jones et al. [46] used immunohistochemistry methods to demonstrate that $H$. pylori do reside in the subjects' colon biopsies and associates with colorectal neoplasm.

Our previous report showed colorectal polyps' incidence begins to increase significantly at age forty in African Americans [47] with or without family history of CRC, thus it has been chosen as a cutoff age in this study. Aging male patients are at a higher risk of adenomatous and hyperplastic polyps [48], and are more likely to associate with $H$. pylori positivity which is consistent with findings in other ethnic groups [49]. In this study, we were not able to establish a correlation between histopathological subtypes, size, and location of colorectal polyps with $H$. pylori infection.

Other confounders such as BMI, smoking, alcohol consumption, diabetes, socioeconomic status, diet and lack of physical activity are known risk factors for colorectal polyp/cancer. Our retrospective epidemiological study did not adjust for these factors because of lack of corresponding information. Previous studies reported an association between $H$. pylori and colorectal adenoma which was not altered even after adjustment for confounding factors $[14,50]$.

To our knowledge, no previous study has linked H. pylori infection with colorectal polyps or cancer in African Americans. The higher prevalence of colorectal polyps in $H$. pylori infected patients and the higher seropositivity could be explained by their environmental and genetic differences as well. Potentially, such differences may alter host gastric and/or colorectal mucosa in response to $H$. pylori carcinogenic effect among some ethnic groups. For instance, Indians have a low rate of gastric cancer and high rate of $H$. pylori infection which was not significantly associated with intestinal metaplasia, gastric tumor site, and patient's age [51]. Moreover, despite the high prevalence of gastric cancer in Finland, there was no association between atrophic gastritis or $H$. pylori infection with colorectal cancer among Finnish male smokers $[19,52]$.

High risk features when combined at presentation were more predictive for colorectal polyps, As such, they can be useful clinical criteria to prioritize access to colonoscopy. The risk prediction of colorectal polyps based on gastric lesions recovered from gastroscopy depend on the nature of such lesions. The highest prevalence of colorectal polyps among $H$. pylori positive subjects was found among those who had chronic active gastritis. Such polyps were more likely to be neoplastic (adenomatous). Due to the retrospective nature of the study, the time lapse between the $H$. pylori infection and the colonic lesions occurrence is unknown. Meira et al. [8] reported after infecting mice with $H$. pylori, the chronic inflammation induced DNA damage in alkyladenine DNA glycosylase deficit mice and enhances inflammationassociated colon tumorigenesis. It also predisposed to the development of gastric cancer precursor lesions.

As gastric lesions progressed, $H$. pylori positivity decreased and the risk of colorectal polyps increased, being highest in patients with chronic atrophic gastritis with intestinal metaplasia, but the number of associated colorectal polyps was too small to make meaningful conclusions. The annual progression from chronic non-atrophic gastritis to atrophic gastritis is 1 to $3 \%[53,54]$. H. pylori in advanced gastric lesions has probably decreased because of migration through the gastrointestinal tract [55]. This suggests that with advanced gastric lesions, gastric lesions but not $H$. pylori status would be appropriate in the prediction of colorectal polyps [23,56,57]. Bulajic et al. [24] found only $1.2 \%$ of malignant colorectal tissues were positive for $H$. pylori in contrast to $6 \%$ positive normal tissues from cancer patients. This could be explained by migration phenomena too [46] and would suggest that $H$. pylori gastric effect could be similar to its colonic effect. Once H. pylori's infection is established, it likely elicits robust and lasting inflammatory and immune responses that may potentially influence the development of diseases that occur later in life such as cancer.

The strengths of our study; are in its comprehensive nature since it linked the real time presence of gastric H. pylori, the symptoms it may produce, and the associated gastric lesions with its extra-gastric colonic effects [58]. Gold standard tools were utilized to diagnose colorectal polyps (complete colonoscopy) and H. pylori infection (gastric biopsy). We used immunohistochemistry to diagnose $H$. pylori in gastric biopsies as it is highly sensitive and specific particularly in patients who have been partially treated. Besides, we had a fairly large sample size $(n=1256)$. Moreover, the findings with this large sample were further confirmed serologically.

Because our study was retrospective and hospitalbased rather than population-based, it has its own limitations. The underestimation of $H$. pylori's prevalence and its associated gastric lesions in the prediction of colorectal polyps could be explained by gastric sampling errors and unknown received treatments. Also, our serology testing sampling was smaller $(n=163)$ than the sampling for the epidemiological study $(n=1256)$. Despite that, we were able to prove positive association between $H$. pylori and colorectal polyps consistent with the 
colon cancer mouse models studies [58]. Also, we were able to show that there is a trend of increased chance of having polyps in the presence of Cag-A positive H. pylori infections.

\section{Conclusions}

In conclusion, forty years and older African Americans with gastric $H$. pylori infection were at high risk of neoplastic and non-neoplastic colonic lesions. H. pylori associated chronic active gastritis and alarming clinical features at presentation may necessitate early screening colonoscopy and/or H. pylori eradication. Prospectively designed studies are needed to establish the conditions in which the current $H$. pylori infection in gastric mucosal lesions might participate in the colon carcinogenic transformation, either through its colonization of the colon and/or through its metabolites and whether the eradication of $H$. pylori would reduce colon polyp incidence in African Americans in the future.

\section{Abbreviations}

AA: African Americans; CRC: Colorectal cancer; IHC: Immunohistochemistry; Gl: Gastrointestinal.

\section{Competing interests}

The authors declare they have no competing interests.

\section{Authors' contributions}

$\mathrm{MZ}$ and $\mathrm{HB}$ contributed equally in acquisition and interpretation of the data, EL contributed in pathology interpretation of results, DS and AOL contributed in sample recruitment, MN and HR performed the statistical analysis, GPP performed H. pylori Cag-A analysis, and HA designed and wrote the paper and submitted the manuscript for publication. All authors read and approved the final manuscript.

\section{Authors' information}

HA is the director of microarray lab at Howard University Cancer Center.

\section{Acknowledgements}

This work was supported by a grant from $\mathrm{NCl}, \mathrm{RCMl}$, grant number: GM12MD007597.

\section{Author details \\ ${ }^{2}$ Department of Medicine and Cancer Center, Howard University, Branch, NJ 07744, USA. \\ Received: 19 August 2013 Accepted: 4 March 2014 Published: 28 April 2014}

'Department of Pathology, Howard University, Washington, DC, USA. Washington, DC, USA. ${ }^{3}$ Sickle Cell Disease Center, Department of Medicine, Howard University, Washington, DC, USA. ${ }^{4}$ Department of Medicine and Microbiology, New York University, New York, NY, USA. ${ }^{5}$ Cancer Center and Department of Medicine, Howard University College of Medicine, 2041 Georgia Avenue, NW, Washington, DC 20060, USA. ${ }^{6}$ Department of Medicine, Monmouth Medical Center, Drexel University College of Medicine, Long

\section{References}

1. Jemal A, Siegel R, Xu J, Ward E: Cancer statistics, 2010. CA Cancer J Clin 2010, 60(5):277-300.

2. Hawkins NJ, Ward RL: Sporadic colorectal cancers with microsatellite instability and their possible origin in hyperplastic polyps and serrated adenomas. J Natl Cancer Inst 2001, 93(17):1307-1313.

3. Jass JR: Hyperplastic-like polyps as precursors of microsatellite-unstable colorectal cancer. Am J Clin Pathol 2003, 119(6):773-775.
4. Kahi CJ, Imperiale TF, Juliar BE, Rex DK: Effect of screening colonoscopy on colorectal cancer incidence and mortality. Clin Gastroenterol Hepatol 2009, 7(7):770-775. quiz 711 .

5. Levin B, Lieberman DA, McFarland B, Andrews KS, Brooks D, Bond J, Dash C, Giardiello FM, Glick S, Johnson D, Johnson CD, Levin TR, Pickhardt PJ, Rex DK, Smith RA, Thorson A, Winawer SJ: Screening and surveillance for the early detection of colorectal cancer and adenomatous polyps, 2008: a joint guideline from the American Cancer Society, the US Multi-Society Task Force on Colorectal Cancer, and the American College of Radiology. Gastroenterology 2008, 134(5):1570-1595.

6. Winawer SJ, Zauber AG, Ho MN, O'Brien MJ, Gottlieb LS, Sternberg SS, Waye JD, Schapiro M, Bond JH, Panish JF, Ackroyd F, Shike M, Kurtz RC, Hornsby-Lewis L, Gerdes H, Stewart ET, and the National Polyp Study Workgroup: Prevention of colorectal cancer by colonoscopic polypectomy. The National Polyp Study Workgroup. N Engl J Med 1993, 329(27):1977-1981.

7. Burnett-Hartman AN, Newcomb PA, Potter JD: Infectious agents and colorectal cancer: a review of Helicobacter pylori, Streptococcus bovis, $\mathrm{JC}$ virus, and human papillomavirus. Cancer Epidemiol Biomarkers Prev 2008, 17(11):2970-2979.

8. Meira LB, Bugni JM, Green SL, Lee CW, Pang B, Borenshtein D, Rickman BH, Rogers AB, Moroski-Erkul CA, McFaline JL, Schauer DB, Dedon PC, Fox JG, Samson LD: DNA damage induced by chronic inflammation contributes to colon carcinogenesis in mice. J Clin Invest 2008, 118(7):2516-2525.

9. Parsonnet J: Bacterial infection as a cause of cancer. Environ Health Perspect 1995, 103(Suppl 8):263-268.

10. Dejea C, Wick E, Sears CL: Bacterial oncogenesis in the colon. Future Microbiol 2013, 8(4):445-460.

11. Fujimori $S$, Kishida T, Kobayashi T, Sekita $Y$, Seo T, Nagata K, Tatsuguchi A, Gudis K, Yokoi K, Tanaka N, Yamashita K, Tajiri T, Ohaki Y, Sakamoto C: Helicobacter pylori infection increases the risk of colorectal adenoma and adenocarcinoma, especially in women. J Gastroenterol 2005, 40(9):887-893.

12. Zhang Y, Gao C, Zhai JH: [Meta-analysis on the relationship between colorectal cancer and Helicobacter pylori infection]. Zhonghua Liu Xing Bing Xue Za Zhi 2009, 30(1):73-77.

13. Zhao YS, Wang F, Chang D, Han B, You DY: Meta-analysis of different test indicators: Helicobacter pylori infection and the risk of colorectal cancer. Int J Colorectal Dis 2008, 23(9):875-882.

14. Zumkeller N, Brenner $\mathrm{H}$, Chang-Claude J, Hoffmeister M, Nieters A, Rothenbacher D: Helicobacter pylori infection, interleukin-1 gene polymorphisms and the risk of colorectal cancer: evidence from a case-control study in Germany. Eur J Cancer 2007, 43(8):1283-1289.

15. D'Onghia V, Leoncini R, Carli R, Santoro A, Giglioni S, Sorbellini F, Marzocca G, Bernini A, Campagna S, Marinello E, Vannoni D: Circulating gastrin and ghrelin levels in patients with colorectal cancer: correlation with tumour stage, Helicobacter pylori infection and BMI. Biomed Pharmacother 2007, 61(2-3):137-141

16. Georgopoulos SD, Polymeros D, Triantafyllou K, Spiliadi C, Mentis A, Karamanolis DG, Ladas SD: Hypergastrinemia is associated with increased risk of distal colon adenomas. Digestion 2006, 74(1):42-46.

17. Hartwich A, Konturek SJ, Pierzchalski P, Zuchowicz M, Labza H, Konturek PC, Karczewska E, Bielanski W, Marlicz K, Starzynska T, Lawniczak M, Hahn EG: Helicobacter pylori infection, gastrin, cyclooxygenase-2, and apoptosis in colorectal cancer. Int J Colorectal Dis 2001, 16(4):202-210.

18. Siddheshwar RK, Gray JC, Kelly SB: Plasma levels of progastrin but not amidated gastrin or glycine extended gastrin are elevated in patients with colorectal carcinoma. Gut 2001, 48(1):47-52.

19. Limburg PJ, Stolzenberg-Solomon RZ, Colbert LH, Perez-Perez GI, Blaser MJ, Taylor PR, Virtamo J, Albanes D: Helicobacter pylori seropositivity and colorectal cancer risk: a prospective study of male smokers. Cancer Epidemiol Biomarkers Prev 2002, 11 (10 Pt 1):1095-1099.

20. Moss SF, Neugut Al, Garbowski GC, Wang S, Treat MR, Forde KA: Helicobacter pylori seroprevalence and colorectal neoplasia: evidence against an association. J Natl Cancer Inst 1995, 87(10):762-763.

21. Robertson DJ, Sandler RS, Ahnen DJ, Greenberg ER, Mott LA, Cole BF, Baron JA: Gastrin, Helicobacter pylori, and colorectal adenomas. Clin Gastroenterol Hepatol 2009, 7(2):163-167.

22. Siddheshwar RK, Muhammad KB, Gray JC, Kelly SB: Seroprevalence of Helicobacter pylori in patients with colorectal polyps and colorectal carcinoma. Am J Gastroenterol 2001, 96(1):84-88. 
23. Bae RC, Jeon SW, Cho HJ, Jung MK, Kweon YO, Kim SK: Gastric dysplasia may be an independent risk factor of an advanced colorectal neoplasm. World J Gastroenterol 2009, 15(45):5722-5726.

24. Bulajic M, Stimec B, Ille T, Jesenofsky R, Kecmanovic D, Pavlov M, Ceranic M, Schneider-Brachert W, Lowenfels A, Maisonneuve P, Lohr J: PCR detection of helicobacter pylori genome in colonic mucosa: normal and malignant. Prilozi 2007, 28(2):25-38.

25. Bulajic M, Stimec B, Jesenofsky R, Kecmanovic D, Ceranic M, Kostic N, Schneider-Brachert W, Lowenfels A, Maisonneuve P, Lohr JM: Helicobacter pylori in colorectal carcinoma tissue. Cancer Epidemiol Biomarkers Prev 2007, 16(3):631-633.

26. Grahn N, Hmani-Aifa M, Fransen K, Soderkvist P, Monstein HJ: Molecular identification of Helicobacter DNA present in human colorectal adenocarcinomas by $16 \mathrm{~S}$ rDNA PCR amplification and pyrosequencing analysis. J Med Microbiol 2005, 54(Pt 11):1031-1035.

27. Jones NL, Day AS, Jennings HA, Sherman PM: Helicobacter pylori induces gastric epithelial cell apoptosis in association with increased Fas receptor expression. Infect Immun 1999, 67(8):4237-4242.

28. Mizuno S, Morita Y, Inui T, Asakawa A, Ueno N, Ando T, Kato H, Uchida M, Yoshikawa T, Inui A: Helicobacter pylori infection is associated with colon adenomatous polyps detected by high-resolution colonoscopy. Int J Cancer 2005, 117(6):1058-1059.

29. Soylu A, Ozkara S, Alis H, Dolay K, Kalayci M, Yasar N, Kumbasar AB: Immunohistochemical testing for Helicobacter Pylori existence in neoplasms of the colon. BMC Gastroenterol 2008, 8:35.

30. WHO (Ed): International Agency for Research on Cancer Monographs. 1994

31. Sonnenberg A: Review article: historic changes of Helicobacter pylori-associated diseases. Aliment Pharmacol Ther 2013, 38(4):329-342.

32. Rokkas T, Sechopoulos P, Pistiolas D, Kothonas F, Margantinis G, Koukoulis G: The relationship of Helicobacter pylori infection and colon neoplasia, on the basis of meta-analysis. Eur J Gastroenterol Hepatol 2013, 25(11):1286-1294

33. Malaty HM, Evans DG, Evans DJ Jr, Graham DY: Helicobacter pylori in Hispanics: comparison with blacks and whites of similar age and socioeconomic class. Gastroenterology 1992, 103(3):813-816.

34. Ford AC, Veldhuyzen van Zanten SJ, Rodgers CC, Talley NJ, Vakil NB, Moayyedi P: Diagnostic utility of alarm features for colorectal cancer: systematic review and meta-analysis. Gut 2008, 57(11):1545-1553.

35. Smoot DT, Collins J, Dunlap S, Ali-lbrahim A, Nouraie M, Lee EL, Ashktorab $\mathrm{H}$ : Outcome of colonoscopy in elderly African-American patients. Dig Dis Sci 2009, 54(11):2484-2487.

36. Griffith KA, McGuire DB, Royak-Schaler R, Plowden KO, Steinberger EK: Influence of family history and preventive health behaviors on colorectal cancer screening in African Americans. Cancer 2008, 113(2):276-285.

37. Correa P: Chronic gastritis: a clinico-pathological classification. Am J Gastroenterol 1988, 83(5):504-509.

38. Perez-Perez Gl, Bhat N, Gaensbauer J, Fraser A, Taylor DN, Kuipers EJ, Zhang L, You WC, Blaser MJ: Country-specific constancy by age in cagA + proportion of Helicobacter pylori infections. Int J Cancer 1997, 72(3):453-456

39. Perez-Perez GI, Dworkin BM, Chodos JE, Blaser MJ: Campylobacter pylori antibodies in humans. Ann Intern Med 1988, 109(1):11-17.

40. Parsonnet J, Blaser MJ, Perez-Perez Gl, Hargrett-Bean N, Tauxe RV: Symptoms and risk factors of Helicobacter pylori infection in a cohort of epidemiologists. Gastroenterology 1992, 102(1):41-46.

41. Perez-Perez Gl, Brown WR, Cover TL, Dunn BE, Cao P, Blaser MJ: Correlation between serological and mucosal inflammatory responses to Helicobacter pylori. Clin Diagn Lab Immunol 1994, 1(3):325-329.

42. Talley NJ, Newell DG, Ormand JE, Carpenter HA, Wilson WR, Zinsmeister AR, Perez-Perez Gl, Blaser MJ: Serodiagnosis of Helicobacter pylori: comparison of enzyme-linked immunosorbent assays. J Clin Microbiol 1991, 29(8):1635-1639.

43. Blaser MJ, Perez-Perez Gl, Kleanthous H, Cover TL, Peek RM, Chyou PH, Stemmermann GN, Nomura A: Infection with Helicobacter pylori strains possessing cagA is associated with an increased risk of developing adenocarcinoma of the stomach. Cancer Res 1995, 55(10):2111-2115.

44. Kuipers EJ, Perez-Perez GI, Meuwissen SG, Blaser MJ: Helicobacter pylori and atrophic gastritis: importance of the cagA status. J Natl Cancer Inst 1995, 87(23):1777-1780.
45. Zumkeller N, Brenner H, Zwahlen M, Rothenbacher D: Helicobacter pylori infection and colorectal cancer risk: a meta-analysis. Helicobacter 2006, 11(2):75-80

46. Jones M, Helliwell P, Pritchard C, Tharakan J, Mathew J: Helicobacter pylori in colorectal neoplasms: is there an aetiological relationship? World J Surg Oncol 2007, 5:51.

47. Kibreab A, Dowlati E, Nouraie M, Brim H, Lee E, Scott V, Smoot DT, Ashktorab H: Colorectal neoplasia in young African Americans, could race be a risk factor? A 40 years experience in an inner city teaching hospital. Gastereoentrology 2009, 136:A337

48. Nouraie M, Hosseinkhah F, Brim H, Zamanifekri B, Smoot DT, Ashktorab H: Clinicopathological features of colon polyps from African-Americans. Dig Dis Sci 2010, 55(5):1442-1449.

49. Giesecke J: An international association between Helicobacter pylori infection and gastric cancer. The EUROGAST Study Group. Lancet 1993, 341(8857):1359-1362.

50. Breuer-Katschinski B, Nemes K, Marr A, Rump B, Leiendecker B, Breuer N, Goebell H: Helicobacter pylori and the risk of colonic adenomas. Colorectal Adenoma Study Group. Digestion 1999, 60(3):210-215.

51. Misra V, Misra SP, Singh MK, Singh PA, Dwivedi M: Prevalence of H. pylori in patients with gastric cancer. Indian J Pathol Microbiol 2007, 50(4):702-707

52. Laiyemo AO, Kamangar F, Marcus PM, Taylor PR, Virtamo J, Albanes D, Stolzenberg-Solomon RZ: Atrophic gastritis and the risk of incident colorectal cancer. Cancer Causes Control 2010, 21(1):163-170.

53. Kuipers EJ, Uyterlinde AM, Pena AS, Roosendaal R, Pals G, Nelis GF, Festen HP, Meuwissen SG: Long-term sequelae of Helicobacter pylori gastritis. Lancet 1995, 345(8964):1525-1528.

54. Villako K, Kekki M, Maaroos HI, Sipponen P, Uibo R, Tammur R, Tamm A: Chronic gastritis: progression of inflammation and atrophy in a six-year endoscopic follow-up of a random sample of 142 Estonian urban subjects. Scand J Gastroenterol Supp/ 1991, 186:135-141.

55. Jung A, Vieth M, Maier O, Stolte M: Fundic gland polyps (Elster's cysts) of the gastric mucosa. A marker for colorectal epithelial neoplasia? Pathol Res Pract 2002, 198(11):731-734

56. Machida-Montani A, Sasazuki S, Inoue M, Natsukawa S, Shaura K, Koizumi Y, Kasuga Y, Hanaoka T, Tsugane S: Atrophic gastritis, Helicobacter pylori, and colorectal cancer risk: a case-control study. Helicobacter 2007 12(4):328-332.

57. Yang MH, Son HJ, Lee JH, Kim MH, Kim JY, Kim YH, Chang DK, Rhee PL, Kim $J$, Rhee JC: Do we need colonoscopy in patients with gastric adenomas? The risk of colorectal adenoma in patients with gastric adenomas. Gastrointest Endosc 2010, 71(4):774-781.

58. Doetschman T: GI GEMs: genetically engineered mouse models of gastrointestinal disease. Gastroenterology 2011, 140(2):380-385. e382.

doi:10.1186/1471-2407-14-296

Cite this article as: Brim et al:: Gastric Helicobacter pylori infection associates with an increased risk of colorectal polyps in African Americans. BMC Cancer 2014 14:296.

\section{Submit your next manuscript to BioMed Central and take full advantage of:}

- Convenient online submission

- Thorough peer review

- No space constraints or color figure charges

- Immediate publication on acceptance

- Inclusion in PubMed, CAS, Scopus and Google Scholar

- Research which is freely available for redistribution 